\title{
Investigasi Perubahan Gaya Belajar Mahasiswa Fakultas Kedokteran: Penelitian Longitudinal
}

\author{
Surya Akbar, ${ }^{1}$ Tezar Samekto Darungan, ${ }^{2}$ Halimah Tania $^{3}$ \\ ${ }^{1,2,3}$ Fakultas Kedokteran Universitas Islam Sumatera Utara, Jl. STM No. 77 Medan \\ ${ }^{1}$ Email: surya.akbar@fk.uisu.ac.id
}

\begin{abstract}
Abstrak
Gaya belajar mahasiswa dapat bervariasi dari visual, auditori, dan kinestetik. Beberapa penelitian memperlihatkan adanya perubahan gaya belajar seiring dengan waktu. Namun, pada beberapa penelitian lainnya hal ini tidak tergambarkan. Penelitian ini bertujuan untuk menganalisis perbedaan gaya belajar mahasiswa selama mengikuti kegiatan belajar mengajar. Desain penelitian kohort digunakan pada penelitian ini. Sebanyak 63 responden mengikuti penelitian ini. Pengukuran dilakukan dua kali, yaitu pada saat responden berada ditahun pertama dan tahun ketiga saat mengikuti program pendidikan dokter. Data yang didapat akan dianalisis secara deskriptif dan analitik. Uji analitik yang digunakan adalah uji alternatif Chi-Square yaitu uji Kolmogorov-Smirnov Z. Hasil pengukuran didapatkan mayoritas gaya belajar mahasiswa baik ditahun pertama atau tahun ketiga dalam kategori unimodal. Gaya belajar unimodal terbanyak adalah visual, diikuti dengan auditori dan kinestetik. Gaya belajar bimodal terbanyak adalah visual kinestetik. Uji komparasi gaya belajar tahun pertama dengan tahun ketiga didapatkan nilai $p=0,832(p<0,05)$. Kesimpulan dari penelitian ini adalah tidak terdapat perbedaan yang signifikan antara gaya belajar mahasiswa ditahun pertama dengan tahun ketiga. Namun, terdapat perubahan gaya belajar mahasiswa seiring dengan waktu. Karakteristik institusi dapat menjadi faktor yang mempengaruhi gaya belajar mahasiswa. Perlu dilakukan penelitian lebih lanjut untuk menganalisis hal tersebut.
\end{abstract}

Kata kunci: Gaya Belajar, VAK, Perubahan.

\section{Investigation of Changes in the Learning Styles of Medical Students: Longitudinal Study}

\author{
Surya Akbar, ${ }^{1}$ Tezar Samekto Darungan, ${ }^{2}$ Halimah Tania ${ }^{2}$ \\ ${ }^{1,2}$ Fakultas Kedokteran Universitas Islam Sumatera Utara, JI. STM No. 77 Medan \\ ${ }^{1}$ Email: surya.akbar@fk.uisu.ac.id
}

\begin{abstract}
Student learning styles can vary from visual, auditory, and kinesthetic. Several studies have shown that learning styles change over time. However, in several other studies, this was not found. This study aims to analyze the differences in student learning styles during the period of teaching and learning activities. The prospective cohort design was used in this study. A total of 63 respondents participated in this study. Measurements were made twice, namely in the first year and the third year. The data obtained will be analyzed descriptively and analytically. The analytical test used is the Chi-Square alternative test, namely the Kolmogorov-Smirnov $Z$ test. The results obtained that most of the student learning styles are in the unimodal category. Most unimodal learning styles are visual, followed by auditory and kinesthetic. The most bimodal learning style is visual kinesthetic. The comparative test of learning styles obtained $p$ value $=0.832(p<0.05)$. The conclusion of this study is that there is no significant difference of students learning styles. However, there are changes in student learning styles over time. The characteristics of an institution can be one of the factors that influence student learning styles. Further research is needed to analyze this.
\end{abstract}

Keywords: Learning Style, VAK, Changes. 


\section{PENDAHULUAN}

Seseorang

dapat mengalami perubahan perilaku dalam menghadapi suatu keadaan atau situasi tertentu akibat adanya memori yang terbentuk pada diri orang tersebut (Ormrod, 2016). Menurut model dual store memory, informasi yang disimpan dalam bentuk memori akan memberi pengetahuan dasar bagi seseorang dalam bersikap atau bertindak terhadap sesuatu (Atkinson \& Shiffrin, 1968). Memori yang berperan dalam perubahan terhadap sikap dan tindakan seseorang tersebut adalah memori jangka panjang. Pembentukan memori jangka panjang perlu melibatkan dua aspek, yaitu aspek tenaga pengajar dan aspek individu pembelajar (Awla, 2014; Ridwan et al., 2019).

Proses belajar sangat erat kaitannya dengan gaya belajar (Dantas \& Cunha, 2020). Gaya belajar pada dasarnya adalah preferensi seseorang dalam menggunakan salah satu jalur penerima infomasi (Pashler et al., 2008). Informasi yang diterima oleh seseorang umumnya dapat berasal dari jalur visual, auditori, kinestetik. Preferensi seseorang dalam menggunakan salah satu dari jalur tersebut akan mengefektifkan pemrosesan informasi yang diterima. Informasi yang diterima harus dapat masuk dalam memori jangka panjang agar dapat tersimpan lama dalam diri seseorang (Ormrod, 2012).
Berdasarkan preferensi jalur masuk informasi yang digunakan maka kita dapat mengelompokkan seseorang dalam 3 gaya belajar, yaitu gaya belajar VAK (Visual, Auditory, Kinesthetic). Gaya belajar ini dipopulerkan oleh Barbe \& Milone Jr (1981) dengan menggunakan istilah modality strenghts. Menurut Barbe \& Milone Jr (1981), modality strenghts adalah jalur informasi yang paling efisien digunakan oleh seseorang untuk menerima dan memproses informasi. Gaya belajar VAK dikemudian hari dikembangkan menjadi gaya belajar VARK.

Secara teori, preferensi jalur informasi yang digunakan seseorang berubah-ubah sesuai dengan usia seseorang (Barbe \& Milone Jr, 1981). Preferensi jalur informasi tersebut tidak dipengaruhi jenis kelamin, ras (genetik), tetapi dianggap dipengaruhi oleh interaksi seseorang dengan sosial dan lingkungannya. Secara teori seseorang dapat memiliki satu atau lebih preferensi jalur informasi (gaya belajar VAK). Seseorang yang memiliki satu preferensi jalur informasi disebut dengan gaya belajar unimodal, sedangkan untuk dua jalur informasi disebut dengan gaya belajar bimodal, dan untuk tiga jalur informasi disebut dengan gaya belajar multimodal.

Penelitian Mitchell et al (2015) terhadap mahasiswa keperawatan dan kebidanan memperlihatkan bahwa lebih 
dari $50 \%$ gaya belajar mereka mengalami perubahan. Perubahan tidak hanya pada antar gaya belajar unimodal saja tetapi juga dari unimodal menjadi multimodal. Namun penelitian tersebut hanya mengukur perubahan gaya belajar mahasiswa dalam jangka waktu 6 bulan saja. Penelitian lainnya membandingkan antara gaya belajar mahasiswa kedokteran gigi tahun pertama dengan tahun kedua diperoleh hasil adanya perbedaan gaya belajar (Aldosari et al., 2018). Penelitian yang menganalisis perbedaan gaya belajar mahasiswa berdasarkan tahun angkatan di mahasiswa keperawatan juga memperoleh hasil yang sama (AlKhasawneh, 2013). Berdasarkan hasil penelitian tersebut didapatkan gaya belajar mahasiswa tingkat atas biasanya memiliki gaya belajar yang lebih multimodal dibandingkan dengan mahasiswa tingkat pertama yang lebih unimodal.

Penelitian-penelitian sebelumnya kebanyakan hanya mencari perbedaan gaya belajar mahasiswa berdasarkan tahun tingkatan pada mahasiswa yang berbeda. Penelitian yang mengikuti perubahan gaya belajar yang terjadi pada pembelajar seiring dengan waktu masih sedikit dilakukan Berdasarkan alasan tersebut, maka peneliti tertarik untuk melihat perubahan gaya belajar mahasiswa dalam jangka panjang, yaitu dari tahun pertama hingga tahun ketiga. Disamping melihat perubahan gaya belajar, peneliti juga akan mengidentifikasi jenis gaya belajar yang dominan dimasingmasing tahun angkatan.

\section{METODE}

Responden dalam penelitian ini adalah mahasiswa Fakultas Kedokteran UISU yang berasal dari dua tahun angkatan yang berbeda, yaitu tahun angkatan 2016 dan tahun angkatan 2017 yang berjumlah 63 orang.

Penelitian ini menggunakan adalah penelitian kuantitatif dengan desain penelitian kohort prospektif. Peneliti mengukur perubahan gaya belajar mahasiswa ditahun pertama (semester I) dan ditahun ketiga (semester III). Pengukuran gaya belajar mahasiswa dilakukan dengan menggunakan kuesioner gaya belajar model VAK (Univesity of California Merced, n.d.). Pengukuran gaya belajar dilakukan setelah mahasiswa mengikuti kuliah pakar saat mahasiswa di semester I dan semester III. Peneliti tetap mendampingi mahasiswa saat pengisian kuesioner berlangsung. Hal ini bertujuan untuk memberikan penjelasan bila mahasiswa mengalami kendala dalam pengisian kuesioner tersebut. Interpretasi gaya belajar mahasiswa dilakukan oleh mahasiswa secara langsung dengan tetap dipandu oleh peneliti. 
Kuesioner VAK menggunakan kuesioner yang dikembangkan oleh University of California (Univesity of California Merced, n.d.). Kuesioner ini terdiri atas 24 kalimat pernyataan dengan 3 pilihan jawaban yaitu sering, kadang-kadang, jarang. Masing-masing pilihan tersebut akan diberi nilai 5, 3, dan 1 . Setiap item pernyataan akan dikelompokkan dalam 3 gaya belajar, yaitu visual, auditori dan kinestetik. Skor tertinggi yang didapat oleh seseorang dari mengisi kuesioner ini akan menentukan gaya belajar yang dimiliki oleh orang tersebut.

Analisa data dimulai dengan melakukan tabulasi data gaya belajar dari mahasiswa semester I dan semester V. Peneliti kemudian mengeluarkan mahasiswa yang memiliki data yang tidak lengkap (hanya gaya belajar di semester I atau semester $\mathrm{V}$ saja). Mahasiswa yang memiliki data gaya belajar yang lengkap akan dilanjutkan dengan analisis deskriptif dan uji komparasi alternatif Chi-Square yaitu uji Kolmogorov-Smirnov Z. Penelitian ini telah mendapat persetujuan etik dari Komisi Etik Penelitian Kesehatan (KEPK) Fakultas Kedokteran UISU. Surat persetujuan etik untuk penelitian ini dengan Nomor 074/EC/KEPK.UISU/ IX/2020.

\section{HASIL DAN PEMBAHASAN}

Sebanyak 63 orang mahasiswa bersedia mengikuti penelitian ini dan memiliki data gaya belajar yang lengkap. Berdasarkan tahun angkatan, sebanyak sebanyak 20 orang mahasiswa $(31,8 \%)$ dari tahun angkatan 2016 mengikuti penelitian ini. Sedangkan untuk tahun angkatan 2017 sebanyak 43 orang mahasiswa $(68,2 \%)$ yang mengikuti penelitian ini.

Gaya belajar terbanyak baik pada mahasiswa tahun pertama maupun mahasiswa tahun ketiga adalah gaya belajar visual. Gaya belajar mayoritas yang dominan pada mahasiswa bersifat unimodal, artinya hanya satu gaya belajar yang dominan pada diri mahasiswa.

Tabel 1. Karakteristik Responden

\begin{tabular}{|c|c|c|c|}
\hline Variabel & $\mathbf{n}$ & \multicolumn{2}{|c|}{$f(\%)$} \\
\hline \multicolumn{4}{|l|}{ Tahun Angkatan } \\
\hline 2016 & \multirow{2}{*}{63} & $20(31,8)$ & \\
\hline 2017 & & $43(68,2)$ & \\
\hline \multicolumn{4}{|l|}{ Jenis Kelamin } \\
\hline Laki-Laki & \multirow{2}{*}{63} & $15(23,8)$ & \\
\hline Perempuan & & $48(76,2)$ & \\
\hline \multicolumn{2}{|l|}{ Kategori Gaya Belajar } & Tahun I & Tahun III \\
\hline Unimodal & \multirow{2}{*}{63} & $55(87,3)$ & $57(90,5)$ \\
\hline Bimodal & & $8(12,7)$ & $3(4,8)$ \\
\hline
\end{tabular}




\begin{tabular}{lcc}
\hline Multimodal & $0(0,0)$ & $3(4,8)$ \\
Gaya Belajar & $f(\%)$ & $f(\%)$ \\
Visual & $28(44,4)$ & $34(54,0)$ \\
Auditori & $14(22,2)$ & $15(23,8)$ \\
Kinestetik & $13(20,6)$ & $8(12,7)$ \\
Visual, Kinestetik & $5(7,9)$ & $0(0,0)$ \\
Visual, Auditori & $1(1,6)$ & $3(4,8)$ \\
Auditori, Kinestetik & $2(3,2)$ & $0(0,0)$ \\
Visual, Auditori, Kinestetik & $0(0,0)$ & $3(4,8)$ \\
\end{tabular}

Tabel 2. Tabel Silang Gaya Belajar Mahasiswa

\begin{tabular}{|c|c|c|c|c|c|c|c|c|}
\hline \multirow{2}{*}{\multicolumn{2}{|c|}{ Gaya Belajar }} & \multicolumn{5}{|c|}{ Semester V } & \multirow[b]{2}{*}{ Total } & \multirow[b]{2}{*}{$p^{*}$} \\
\hline & & Visual & Auditori & Kinestetik & Visual, & $\begin{array}{c}\text { Visual, } \\
\text { Auditori, }\end{array}$ & & \\
\hline \multirow{6}{*}{$\begin{array}{c}\text { SMT } \\
\text { I }\end{array}$} & Visual & $19(30,2)$ & $5(7,9)$ & $2(3,2)$ & $1(1,6)$ & $1(1,6)$ & $\begin{array}{c}28 \\
(44,4)\end{array}$ & \multirow{6}{*}{0,832} \\
\hline & Auditori & $3(4,8)$ & $8(12,7)$ & $1(1,6)$ & $1(1,6)$ & $1(1,6)$ & $\begin{array}{c}14 \\
(22,2)\end{array}$ & \\
\hline & Kinestetik & $7(11,1)$ & $1(1,6)$ & $4(6,3)$ & $1(1,6)$ & $0(0,0)$ & $\begin{array}{c}13 \\
(20,6)\end{array}$ & \\
\hline & \multirow{3}{*}{$\begin{array}{c}\text { Visual, Kinestetik } \\
\text { Visual, Auditori } \\
\text { Auditori, } \\
\text { Kinestetik }\end{array}$} & $4(6,3)$ & $1(1,6)$ & $0(0,0)$ & $0(0,0)$ & $0(0,0)$ & $\begin{array}{c}5 \\
(7,9 \%)\end{array}$ & \\
\hline & & $1(1,6)$ & $0(0,0)$ & $0(0,0)$ & $0(0,0)$ & $0(0,0)$ & $1(1,6)$ & \\
\hline & & $0(0,0)$ & $0(0,0)$ & $1(1,6)$ & $0(0,0)$ & $1(1,6)$ & $2(3,2)$ & \\
\hline & Total & $34(54,0)$ & $\begin{array}{c}15 \\
(23,8)\end{array}$ & $8(12,7)$ & $3(4,8)$ & $3(4,8)$ & $\begin{array}{c}63 \\
(100)\end{array}$ & \\
\hline
\end{tabular}

*) Uji Kolmogorov-Smirnov Z (Uji alternatif Chi-Square karena syarat uji Chi-Square tidak terpenuhi).

Tabel 3. Tabel Silang Kategori Gaya Belajar Mahasiswa

\begin{tabular}{|c|c|c|c|c|c|c|}
\hline \multirow{2}{*}{\multicolumn{2}{|c|}{ Gaya Belajar }} & \multicolumn{3}{|c|}{ Semester V } & \multirow{2}{*}{ Total } & \multirow{2}{*}{$p^{*}$} \\
\hline & & Unimodal & Bimodal & Multimodal & & \\
\hline \multirow{3}{*}{ SMT I } & Unimodal & $50(79,4)$ & $3(4,8)$ & $2(3,2)$ & $55(87,3)$ & \multirow{3}{*}{1,000} \\
\hline & Bimodal & $7(11,1)$ & $0(0,0)$ & $1(1,6)$ & $8(12,7)$ & \\
\hline & Multimodal & $0(0,0)$ & $0(0,0)$ & $0(0,0)$ & $0(0,0)$ & \\
\hline & Total & $57(90,5)$ & $3(4,8)$ & $3(4,8)$ & $63(100,0$ & \\
\hline
\end{tabular}

*) Uji Kolmogorov-Smirnov Z (Uji alternatif Chi-Square karena syarat uji Chi-Square tidak terpenuhi.

Analisis komparasi antara gaya belajar mahasiswa di tahun pertama dengan tahun ketiga tidak didapatkan perbedaan yang signifikan $(p>0,05)$. Begitupula uji komparasi kategori gaya belajar (uni, bi, multimodal) pada mahasiswa di tahun pertama dengan tahun ketiga juga tidak ditemukan perbedaan yang signifikan. 
Berdasarkan tabel silang, dapat dilihat bahwa pada mahasiswa tahun pertama yang memiliki gaya belajar visual mayoritas tetap memiliki gaya belajar visual di tahun ketiga $(30,2 \%)$. Untuk mahasiswa yang memiliki gaya belajar auditori di tahun pertama mayoritas juga masih memiliki gaya belajar auditori di tahun ketiga $(12,7 \%)$, namun banyak juga gaya belajar mahasiswa yang berubah ke visual di tahun ketiga (4,8\%). Mahasiswa yang memiliki gaya belajar kinestetik di tahun pertama mayoritas mengalami perubahan ditahun ketiga menjadi gaya belajar visual $(11,1 \%)$.

Pada tabel 3 memperlihatkan bahwa secara umum gaya belajar mahasiswa masih dalam kategori unimodal. Bahkan dari tabel tersebut terlihat mayoritas gaya belajar bimodal berubah menjadi unimodal di tahun ketiga $(11,1 \%)$.

Gaya belajar pada mahasiswa umumnya dapat memiliki gaya belajar dalam kategori unimodal, bimodal ataupun multimodal. Pada penelitian ini mayoritas mahasiswa memiliki kategori unimodal. Hasil ini seperti sama seperti pada penelitian lainnya dimana mayoritas memiliki gaya belajar dikategorikan unimodal (Marwaha et al., 2019; Saga et al., 2015). Namun, beberapa penelitian memiliki hasil yang berbeda, dimana mayoritas mahasiswa memiliki gaya belajar dalam kategori bimodal atau multimodal
(Balasubramaniam \& Indhu, 2016; Karim et al., 2019; Kharb et al., 2013). Perbedaan ini bisa disebabkan adanya perbedaan proses belajar mengajar yang diterapkan dimasingmasing institusi pendidikan. Bila proses pengajaran yang dilakukan menggunakan metode pembelajaran yang mengharuskan mahasiswa menggunakan jalur visual, auditori, dan kinestetik maka mahasiswa tersebut akan menggunakan gaya belajar dalam kategori multimodal atau bimodal. Tetapi bila pengajaran yang dilakukan mengharuskan mahasiswa menerapkan penggunaan satu jalur informasi saja, maka gaya belajar yang akan terbentuk mayoritas dikategori unimodal.

Gaya belajar unimodal yang terbanyak dalam penelitian ini ada pada gaya belajar visual. Berbeda dengan penelitian ini, beberapa penelitian terhadap mahasiswa kedokteran dan kedokteran gigi memiliki gaya belajar kinestetik (Balasubramaniam \& Indhu, 2016; Kharb et al., 2013; Marwaha et al., 2019; Saga et al., 2015). Sama seperti penjelasan di atas, perbedaan yang terjadi antara penelitian ini dengan penelitian lainnya dapat disebabkan adanya perbedaan proses belajar mengajar yang dilakukan dimasing-masing institusi pendidikan. Gaya belajar kinestetik yang lebih dominan dapat diartikan bahwa proses belajar mengajar lebih 
mengutamakan pelatihan keterampilan dari pada kuliah atau diskusi tutorial.

Gaya belajar bimodal yang terbanyak dari penelitian ini ada pada gaya belajar visual dan kinestetik. Penelitian lain mendapatkan mayoritas gaya belajar bimodal yang pada mahasiswa kedokteran atau kedokteran gigi ada pada gaya belajar visual kinestetik (Balasubramaniam \& Indhu, 2016; Karim et al., 2019; Prithishkumar \& Michael, 2014). Gaya belajar mahasiswa merupakan cerminan dari proses belajar yang diberikan kepada mahasiswa tersebut. Hal ini dapat menjadi masukan dalam mengevaluasi pelaksanaan kegiatan belajar mengajar di suatu institusi dalam rangka membentuk lulusan yang siap menjalankan profesinya kelak. Profesi yang mengharuskan penguasaan suatu keterampilan tertentu yang menunjang profesinya maka harus menekankan pada pelatihan keterampilan. Bila suatu profesi mengharuskan kemampuan analisis dan kognitif yang baik maka kegiatan belajar mengajar sebaiknya menekankan pada diskusi atau kuliah.

Hasil uji komparasi antara gaya belajar mahasiswa ditahun pertama dengan tahun ketiga memperlihatkan tidak ada perbedaan yang signifikan. Hasil penelitian ini sama seperti penelitian yang dilakukan pada mahasiswa kedokteran gigi untuk melihat perubahan gaya belajar mahasiswa setelah mengikuti pendidikan selama 4 tahun (Marwaha et al., 2019). Meskipun begitu, hasil ini berbeda dengan penelitianpenelitian lain yang mendapatkan bahwa terdapat perubahan gaya belajar berdasarkan waktu (Aldosari et al., 2018; AlKhasawneh, 2013; Mitchell et al., 2015). Perbedaan hasil penelitian ini mungkin disebabkan adanya perbedaan gaya belajar sebelum mahasiswa masuk ke institusi pendidikan dengan setelah mengikuti kegiatan belajar mengajar. Sistem seleksi yang diterapkan oleh suatu institusi dapat menyeleksi gaya belajar tertentu dari calon mahasiswa (Johnson, 2009). Seleksi tersebut akan mempersiapkan mahasiswa untuk mengikuti kegiatan belajar mengajar yang dikhususkan pada gaya belajar tertentu sesuai dengan karakteristik institusi tersebut. Bila dilakukan penilaian kembali terhadap gaya belajar mahasiswa yang telah mengikuti proses belajar mengajar, maka bisa saja gaya belajar mahasiswa tersebut akan sama dengan gaya belajar saat mahasiswa tersebut mengikuti seleksi masuk. Hal inilah yang mungkin dapat menjelaskan mengapa tidak terjadi perubahan gaya belajar pada penelitian-penelitian tersebut.

Karakteristik dari institusi pendidikan dapat dilihat dari karakteristik pengajaran, materi yang diajarkan, dan penilaian yang dilakukan (Newble \& Entwistle, 1986). Jenis 
atau kedalam dari proses penilaian yang diterapkan oleh suatu institusi juga dapat mempengaruhi gaya belajar mahasiswa (Akbar, 2020). Maka dari itu, perubahan pada gaya belajar mahasiswa juga dapat dipengaruhi oleh karakteristik pengajaran dari suatu institusi. Gambaran gaya belajar dan perubahan gaya belajar yang terjadi pada mahasiswa di suatu institusi pendidikan dapat menggambarkan karakteristik dari institusi tersebut dalam melaksanakan proses pendidikan.

Walaupun tidak diperoleh perbedaan yang bermakna antara gaya belajar mahasiswa ditahun ketiga dengan tahun pertama, namun secara deskriptif (tabel silang) dapat terlihat adanya perubahan gaya belajar mahasiswa. Pada tabel 2 terlihat bahwa gaya belajar mahasiswa yang mengalami perubahan lebih berfokus pada gaya belajar visual. Hal ini dapat diartikan bahwa karakteristik proses belajar mengajar di FK UISU lebih berfokus dalam menggunakan jalur informasi visual dibandingkan dengan jalur informasi lainnya.

Mahasiswa sebagai seorang pembelajar memiliki kemampuan dalam adaptasi gaya belajar yang digunakannya sesuai dengan karakteristik pengajaran suatu institusi (Brown, 2003). Penerapan suatu metode pembelajaran tertentu dapat mengubah cara belajar mahasiswa (Weng et al., 2019). Perubahan cara belajar tersebut pada akhirnya akan mengubah gaya belajar mahasiswa. Maka dari itu, penilaian gaya belajar sebaiknya tidak digunakan untuk menentukan gaya mengajar (teaching style) yang harus diberikan kepada mahasiswa. Penilaian gaya belajar sebaiknya digunakan untuk menilai kesesuaian karakteristik pengajaran suatu institusi dengan karakteristik lulusan yang diharapkan. Hal ini dikarenakan gaya belajar merupakan cerminan karakteristik pengajaran dari suatu institusi, sehingga untuk memastikan karakteristik pengajaran dapat mencapai karakteristik lulusan maka gaya belajar mahasiswa mungkin kedepannya dapat digunakan sebagai salah satu alat evaluasi.

Penelitian ini memiliki beberapa keterbatasan, diantaranya adalah besar sampel yang digunakan tidak cukup besar, variabel lain (karakteristik responden) tidak ikut dianalisis, karakteristik institusi tidak ikut dinilai. Hasil penelitian ini hanya menggambarkan perubahan gaya belajar mahasiswa di Fakultas Kedokteran UISU, sehingga generalisasi hasil penelitian ini kedalam lokasi lain belum dapat dilakukan. Walaupun begitu, hasil dari penelitian ini dapat digunakan sebagai dasar untuk penelitian lebih lanjut terhadap gaya belajar. 


\section{SIMPULAN DAN SARAN}

Gaya belajar mahasiswa antara tahun pertama dengan tahun ketiga tidak berbeda secara bermakna. Meskipun begitu, didapatkan perubahan gaya belajar mahasiswa seiring dengan waktu. Perubahan gaya belajar dapat dipengaruhi oleh karakteristik suatu institusi dalam melaksanakan kegiatan belajar mengajar. Gaya belajar dapat digunakan sebagai alat evaluasi pelaksanaan kegiatan belajar mengajar suatu institusi. Penelitian lebih lanjut untuk menganalisis karakteristik pengajaran suatu institusi terhadap gaya belajar perlu dilakukan.

\section{DAFTAR REFERENSI}

Akbar, S. (2020). Changes in Learning Style: Does it Change? South-East Asian Journal of Medical Education, 14(2), 150-152. https://doi.org/10.4038/seajme.v14i2.249

Aldosari, M. A., Aljabaa, A. H., Al-Sehaibany, F. S., \& Albarakati, S. F. (2018). Learning style preferences of dental students at a single institution in Riyadh, Saudi Arabia, evaluated using the VARK questionnaire. Advances in Medical Education and Practice, $\quad 9$, 179-186. https://doi.org/10.2147/AMEP.S157686

AlKhasawneh, E. (2013). Using VARK to assess changes in learning preferences of nursing students at a public university in Jordan: Implications for teaching. Nurse Education Today, 33(12), 1546-1549. https://doi.org/10.1016/j.nedt.2012.12.01 7

Atkinson, R. ., \& Shiffrin, R. . (1968). Human memory: a proposed system and its control processes. Psychology of Learning and Motivation, 2, 89-195.

Awla, H. A. (2014). Learning Styles and Their Relation to Teaching Styles. International Journal of Language and Linguistics, 2(3), 241-245. https://doi.org/10.11648/j.ijll.20140203.2
3

Balasubramaniam, G., \& Indhu, K. (2016). A Study of Learning Style Preferences among First Year Undergraduate Medical Students Using VARK Model. Education in Medicine Journal, 8(4), 15-21. https://doi.org/10.5959/eimj.v8i4.440

Barbe, W. B., \& Milone Jr, M. N. (1981). What we know about modality strengths. Educational Leadership, 38, 378-380.

Brown, B. L. (2003). Teaching Style vs Learning Style. ERIC, 26, 1-2.

Dantas, L. A., \& Cunha, A. (2020). An integrative debate on learning styles and the learning process. Social Sciences \& Humanities Open, 2, 1-5. https://doi.org/10.1016/j.ssaho.2020.100 017

Johnson, M. (2009). Evaluation of Learning Style for First Year Medical Students. International Journal for the Scholarship of Teaching and Learning, 3(1), 1-15. https://doi.org/10.20429/ijsotl.2009.0301 20

Karim, M. R., Asaduzzaman, A., Talukder, M. H. K., Alam, K. K., Haque, F., \& Khan, S. J. (2019). Learning Style Preferences Among Undergraduate Medical Students: An Experience from Different Medical Colleges of Bangladesh. Bangladesh Journal of Medical Education, 10(2), 2630.

https://doi.org/10.3329/bjme.v10i2.44640

Kharb, P., Samanta, P. P., Jindal, M., \& Singh, V. (2013). The learning styles and the preferred teaching-learning strategies of first year medical students. Journal of Clinical and Diagnostic Research, 7(6), 1089-1092.

https://doi.org/10.7860/JCDR/2013/5809. 3090

Marwaha, K., Sharma, U., Bhagat, A., \& Kapoor, N. (2019). Learning Preferences of Undergraduate Dental Students: A longitudinal Assessment Over Four Years. Indian Journal of Physiology and Pharmacology, 63(2), 182-188.

Mitchell, E. K. L., James, S., \& Damore, A. (2015). How learning styles and preferences of first-year nursing and midwifery students change. Australian Journal of Education, 59(2), 158-168. https://doi.org/10.1177/00049441155879 17

Newble, D. I., \& Entwistle, N. J. (1986). Learning 
styles and approaches: implications for medical education. Medical Education, 20(3), 162-175. https://doi.org/10.1111/j.13652923.1986.tb01163.x

Ormrod, J. E. (2012). Human learning 6th edition. In Pearson Education, Inc (Vol. 91).

Ormrod, J. E. (2016). Human Learning (7th ed.). Pearson Education.

Pashler, H., McDaniel, M., Rohrer, D., \& Bjork, R. (2008). Learning styles: concepts and evidence. Psychological Science in the Public Interest, 9(2), 105-119. https://doi.org/10.1177/00336882030340 0205

Prithishkumar, I. J., \& Michael, S. A. (2014). Understanding your student: Using the VARK model. Journal of Postgraduate Medicine, 60(2), 183-186. https://doi.org/10.4103/00223859.132337

Ridwan, H., Sutresna, I., \& Haryeti, P. (2019).
Teaching styles of the teachers and learning styles of the students. Journal of Physics: Conference Series, 1318(1). https://doi.org/10.1088/17426596/1318/1/012028

Saga, Z., Qamar, K., \& Trali, G. (2015). Learning Styles-Understanding for Learning Strategies. Medical Education, 65(5), 706709.

Univesity of California Merced. (n.d.). Learning Style Questionnaire. Retrieved January 25, 2021 from https://learning.ucmerced.edu/learningtools/resources

Weng, F., Ho, H. J., Yang, R. J., \& Weng, C. H. (2019). The influence of learning style on learning attitude with multimedia teaching materials. Eurasia Journal of Mathematics, Science and Technology Education, 15(1), 1-9. https://doi.org/10.29333/ejmste/100389 